\title{
Uji Residu Antibiotika pada Hati Sapi Bali di Beberapa Pasar Daerah di Provinsi Bali
}

\author{
(ANTIBIOTICS RESIDUE TEST ON THE LIVER OF BALI CATTLE IN SOME \\ TRADITIONAL MARKETS IN BALI PROVINCE)
}

\author{
Alexander Jacky Cundawan ${ }^{1 *}$, I Wayan Sudira ${ }^{1}$, Siswanto ${ }^{2}$ \\ ${ }^{1}$ Laboratorium Farmakologi dan Farmasi Veteriner, ${ }^{2}$ Laboratorium Fisiologi Veteriner, \\ Fakultas Keokteran Hewan, Universitas Udayana. Jl. PB. Sudirman, Denpasar-Bali. \\ *Email: alexyath33@gmail.com
}

\begin{abstract}
ABSTRAK
Keberadaan residu antibiotika dalam makanan asal hewan (misalnya hati sapi bali) erat kaitannya dengan penggunaan antibiotika untuk pengobatan penyakit dan penggunaan sebagai imbuhan pakan. Penelitian ini bersifat survey yang bertujuan mengetahui ada tidaknya residu antibiotika dalam hati sapi bali yang dipasarkan di beberapa pasar daerah di Provinsi Bali, yaitu Kabupaten Jembrana, Singaraja, Tabanan, Gianyar dan Karangasem. Penelitian ini menggunakan 30 sampel yang diambil secara acak, yaitu enam sampel dari dua pasar dalam satu kabupaten. Pengambilan sampel dilakukan tiga pengulangan pada setiap pasar dengan pedagang yang berbeda. Pengujian residu antibiotika menggunakan metode uji bioassay (screening test). Hasil penelitian menunjukkan bahwa hati sapi bali yang dipasarkan di beberapa pasar daerah di Provinsi Bali tidak mengandung residu antibiotika.
\end{abstract}

Kata kunci: Antibiotika; bioassay; hati; residu; sapi bali.

\begin{abstract}
The presence of antibiotic residues in food of animal origin (eg. bali cattle liver) is closely related to the use of antibiotics for the treatment of diseases and use as feed additives. This study is a survey that aims to determine whether there is antibiotic residue in the liver of Bali cattle marketed in several regional markets in Bali Province, namely Jembrana, Singaraja, Tabanan, Gianyar and Karangasem districts. This study used 30 samples taken at random, 6 samples from 2 markets in 1 district. Sampling conducted 3 repetitions on each market with different traders. Testing of antibiotic residues using bioassay test method (screening test). The results showed that Bali's liver cattle marketed in several regional markets in Bali Province did not contain antibiotic residues.
\end{abstract}

Keywords: antibiotic; bali cattle; bioassay; liver; residue.

\section{PENDAHULUAN}

Sapi bali merupakan bangsa sapi pedaging lokal yang memiliki potensi genetik sangat baik serta keunggulan sebagai penghasil daging yang sangat potensial. Selain daging, produk asal sapi yang dapat diperoleh adalah jeroan, yang merupakan bagian-bagian dalam tubuh (hewan) yang sudah dipotong. Jeroan adalah semua bagian dalam dari pemotongan sapi kecuali otot dan tulang. Di berbagai daerah Indonesia, hampir semua bagian jeroan dimasak untuk makanan manusia, contohnya antara lain adalah rendang otak, paru-paru goreng, usus goreng, sate hati, rendang lidah, dan sebagainya. Sapi Bali dikenal sebagai sapi lokal yang banyak dipelihara di Pulau Bali, karena sangat menguntungkan peternak disamping cara pemeliharaannya yang mudah dan sifatnya yang mampu beradaptasi baik pada lingkungan (Dewi et al., 2016).

Secara alami, sapi bali memiliki kemampuan beradaptasi sangat baik terhadap kondisi lingkungan tropis, sifat tidak selektif terhadap pakan, serta mampu memberikan respon pertumbuhan yang baik terhadap kondisi dan kualitas lingkungan pemeliharaan yang sederhana (Suranjaya et al., 2010), sehingga sapi bali banyak dijadikan hewan ternak oleh masyarakat Indonesia. Sapi bali ini memiliki hubungan yang erat dengan 
masyarakat di Bali dan tidak hanya dijadikan sebagai ternak untuk tujuan komersial, namun memiliki fungsi lain yaitu sebagai pekerja dan dipergunakan untuk upacara adat (Gunawan et al., 2016). Status kesehetan sapi bali dalam berternak perlu diperhatikan untuk menghasilkan produksi yang maksimal. Peternak sering menggunakan antibiotika untuk mempertahankan kesehatan ternaknya. Penggunaan obat-obatan dalam usaha peternakan hampir tidak dapat dihindarkan, karena ternak diharapkan selalu berproduksi secara optimal sehingga kesehatan ternak selalu terjaga. Untuk memenuhi tuntutan produksi ternak yang tinggi, maka ketersediaan obat hewan sangat diperlukan, di samping penggunaan bibit unggul. Antibiotika digunakan untuk membasmi bakteri penyebab terjadinya infeksi.

Antibiotika adalah zat yang dapat membunuh atau menghambat pertumbuhan bakteri dan yang terkait dengan mikroorganisme dan sangat penting dalam pengobatan manusia dan hewan. Pada dasarnya suatu infeksi bakteri dapat ditangani oleh sistem pertahanan tubuh namun adakalanya sistem ini perlu ditunjang oleh penggunaan antibiotika. Antibiotika yang paling sering dideteksi dalam daging yaitu penisilin (termasuk ampisilin), tetrasiklin (termasuk khlortetrasiklin dan oksitetrasiklin), sulfonamid (termasuk sulfadimethoksin, sulfamethazin dan sulfamethoksazol), neomisin, gentamisin, dan streptomisin).

Keberadaan residu antibiotika dalam makanan asal hewan erat kaitannya dengan penggunaan antibiotika untuk pengobatan penyakit dan penggunaan sebagai imbuhan pakan. Pencampuran bahan baku imbuhan pakan dalam ransum yang dilakukan sendiri di tempat peternakan yang kurang dapat dijamin ketepatan takarannya dapat menyebabkan residu pada pangan asal hewan (Masrianto et al., 2013). Marlina et al., (2015) menunjukkan bahwa 13 dari 48 sampel daging dan hati ayam di Kecamatan Pamijahan, Kabupaten Bogor, Jawa Barat positif mengandung residu antibiotika golongan makrolida dan tetrasiklin. Sampel hati yang positif makrolida mencapai 45,83\% (11 dari 24 sampel hati). Sampel yang positif tetrasiklin meliputi sampel hati 4,17\% (1 dari 24 sampel hati) dan sampel daging paha $4,17 \%$ (1 dari 24 sampel daging paha).

Praktik perilaku seperti penggunaan antibiotika berlebihan pada penanganan infeksi dan kurangnya pemahaman tentang penggunaan antibiotika juga berkontribusi terhadap kontaminasi makanan (Lee et al., 2001). Kehadiran antibiotika dalam pakan ternak dan produk olahan ternak dapat menimbulkan beberapa efek kesehatan pada masyarakat yang merugikan termasuk hipersensitivitas, kerusakan jaringan, gangguan saluran cerna, dan gangguan neurologis (Wessenaar, 2005).

Residu antibiotika dalam pangan dapat mengancam kesehatan masyarakat. Nina et al., (2015) menyatakan bahwa residu dapat ditemukan akibat penggunaan obat-obatan, termasuk antibiotika, pemberian feed additive ataupun hormon pemacu pertumbuhan hewan. Senyawa obat yang masuk kedalam tubuh ternak tidak dapat seluruhnya diekskresi dari jaringan dan akan tertahan dalam jaringan tubuh sebagai residu. Donkor et al., (2011) melaporkan bahwa prevalensi residu obat hewan di Ghana sebanyak $21,1 \%$ dalam sampel produk asal hewan. Adanya praktik pengobatan hewan (sapi) sakit dengan menggunakan antibiotika sering dilakukan oleh peternak sendiri. Penggunaan antibiotika yang tidak memperhatikan masa henti obat akan menimbulkan residu antibiotika pada produk pangan hewan.

Produk pangan asal hewan sapi bali, salah satunya hati, dapat ditinjau untuk mengkonfirmasi dan sebagai monitoring keberadaan residu antibiotika. Hati merupakan salah satu organ penting dalam tubuh. Organ ini penting untuk sekresi empedu, detoksifikasi atau degradasi zat sisa hormon serta obat dan senyawa asing lainnya. Hati mempunyai banyak tempat untuk mengikat senyawa-senyawa yang 
tidak bisa terdetoksifikasi atau tidak bisa disekresikan. Hati juga merupakan tempat utama untuk metebolisme (biotransformasi) sebagian besar obat. Sehingga menyebabkan kadar residu obat termasuk antibiotika dalam hati menjadi lebih tinggi dibandingkan kadar residu dalam jaringan lain (Putri et al., 2015).

Berdasarkan latar belakang diatas, penelitian ini bertujuan untuk mengetahui apakah dalam hati sapi yang dipasarkan di beberapa pasar kota di Provinsi Bali mengandung residu antibiotika atau tidak. Diharapkan dari hasil pengamatan akan memberikan informasi terhadap masyarakat, sehingga masyarakat akan lebih berhati-hati dalam mengkonsumsi hati sapi.

\section{METODE PENELITIAN}

Sampel yang digunakan dalam penelitian ini adalah 30 sampel. Menurut Cohen et al., (2007) semakin besar sampel dari besarnya populasi yang ada adalah semakin baik, akan tetapi ada jumlah batas minimal yang harus diambil oleh peneliti yaitu sebanyak 30 sampel. Sampel hati sapi bali diperoleh dari beberapa pasar tradisional di Provinsi Bali, yaitu pasar di Kabupaten Jembrana, Kabupaten Tabanan, Kabupaten Buleleng, Kabupaten Karangasem dan Kabupaten Gianyar. Pemilihan lokasi kabupaten dipilih dengan memperhatikan topografi wilayah Provinsi Bali. Jumlah pasar yang dijadikan sasaran penelitian tersebut adalah dua pasar di setiap kabupaten yang di jadikan tempat pengambilan sampel di Provinsi Bali. Penentuan pengambilan sampel dilakukan secara acak dan dilakukan 3 pengulangan pada setiap pasar. Sampel tersebut diperoleh dari pedagang yang berbeda disetiap pasar.

Alat-alat yang digunakan dalam penelitian ini yaitu: cawan petri, tabung reaksi, tabung sentrifus, labu ukur, gelas ukur, erlenmeyer, botol timbang, pipet volumetric, pipet graduasi, botol media, pengocok tabung, sentrifus, penangas air, lemari steril, homogenizer, autoklaf, lemari pendingin, freezer, timbangan analitik, inkubator, magnet pengaduk, $\mathrm{pH}$ meter, pipet mikro, jangka sorong, burner, ose, pinset, dan gunting (SNI No. 7424:2008).

Bahan-bahan yang digunakan dalam penelitian ini yaitu: media agar, larutan buffer $\left(\mathrm{KH}_{2} \mathrm{PO}_{4}, \mathrm{Na}_{2} \mathrm{HPO}_{4}, \mathrm{H}_{3} \mathrm{PO}_{4}, \mathrm{NaOH}\right.$, $\mathrm{K}_{2} \mathrm{HPO}_{4}, \mathrm{HCl}, \mathrm{NaCl}$ ), mikroorganisme (spora Bacillus stearothermophilus ATCC 7953, spora Bacillus cereus ATCC 11778, spora Bacillus subtillis ATCC 6633, vegetatif Kocuria rizophila ATCC 9341), larutan baku pembanding (natrium penisilin, oksitetrasiklin hidroklorida, kanamisin sulfat, tilosin-tartrat), dan kertas cakram (SNI No. 7424:2008).

Kultur media disiapkan untuk masingmasing golongan antibiotika. Tiap cawan petri berisi lima lembar kertas cakram, yang terdiri dari tiga kertas cakram masingmasing ditetesi $75 \mu \mathrm{l}$ sampel yang akan dianalisa, satu kertas yang ditetesi $75 \mu \mathrm{l}$ dari larutan baku pembanding sebagai kontrol positif, dan satu kertas yang ditetesi larutan dapar fosfat sebagai kontrol negatif. Kertas cakram tersebut diletakkan di atas permukaan kultur media. Cawan petri ditutup dan diinkubasi pada suhu yang berbeda tergantung golongan antibiotika. (golongan tetrasiklin $30^{\circ} \mathrm{C} \pm 1^{\circ} \mathrm{C}$, golongan penisilin $55^{\circ} \mathrm{C} \pm 1{ }^{\circ} \mathrm{C}$, golongan makrolida dan aminoglikosida $36{ }^{\circ} \mathrm{C} \pm 1{ }^{\circ} \mathrm{C}$ ) masingmasing selama 16-18 jam. Untuk mendapatkan data yang akurat maka pengujian sampel dilakukan dengan tiga kali pengulangan sehingga setiap jenis golongan antibiotika menggunakan tiga cawan petri.

Hasil uji ditentukan dengan mengamati dan mengukur diameter zona hambatan yang terbentuk di sekeliling kertas cakram menggunakan jangka sorong. Apabila di sekitar kertas cakram terdapat zona hambatan (minimal $2 \mathrm{~mm}$ lebih besar dari diameter kertas cakram) maka hati yang diperiksa dinyatakan positif mengandung antibiotika, namun apabila di sekitar kertas cakram tidak terdapat zona hambatan maka hati yang diperiksa dinyatakan negatif mengandung residu antibiotika. 


\section{HASIL DAN PEMBAHASAN}

Hasil uji dari 30 sampel hati sapi bali menggunakan metode bioassay, didapat bahwa keseluruhan sampel menunjukkan hasil negatif residu antibiotika (Tabel 1), ditandai dengan tidak terbentuknya daerah hambatan dan terbentuknya daerah hambatan yang berada dibawah standar nasional (SNI 7424:2008).

Tabel 1. Hasil pemeriksaan secara bioassay residu antibiotika golongan tetrasiklin, penisilin, aminoglikosida, dan makrolida pada hati sapi bali

\begin{tabular}{ccccccc}
\hline \multirow{2}{*}{ No } & Jumlah & \multirow{2}{*}{ Kampel } & Kabupaten & \multicolumn{4}{c}{ Golongan Antibiotika } \\
\cline { 4 - 7 } & setrasiklin & Penisilin & Makrolida & Aminoglikosida \\
\hline 1 & 6 & Jembrana & Negatif & Negatif & Negatif & Negatif \\
2 & 6 & Buleleng & Negatif & Negatif & Negatif & Negatif \\
3 & 6 & Tabanan & Negatif & Negatif & Negatif & Negatif \\
4 & 6 & Gianyar & Negatif & Negatif & Negatif & Negatif \\
5 & 6 & Karangasem & Negatif & Negatif & Negatif & Negatif \\
\hline
\end{tabular}

Sasaran utama dari penelitian ini adalah untuk mengetahui ada tidaknya residu antibiotika golongan penisilin, tetrasiklin, makrolida dan aminoglikosida pada hati sapi bali di beberapa pasar daerah di Provinsi Bali. Berdasarkan hasil pemeriksaan secara kualitatif dengan metode bioassay (Tabel 1) menunjukkan bahwa tidak terdapat residu antibiotika.

Tidak ditemukannya residu antibiotika dari golongan penisilin, aminoglikosida, tetrasiklin, dan makrolida pada seluruh sampel yang diuji dapat disebabkan oleh beberapa hal. Pertama, hal ini dapat disebabkan karena sapi bali yang dipotong dan dipasarkan di pasar daerah merupakan hasil peternakan tradisional masyarakat dan tidak menggunakan antibiotika dalam pakan. Kedua, hasil negatif tersebut dapat disebabkan karena hewan yang dipotong dan dipasarkan bukan merupakan hewan sakit yang sedang dalam proses pengobatan (antibiotika) dan apabila sedang dalam proses pengobatan (antibiotika) peternak sudah memperhatikan masa henti obat (withdrawal time). Ketiga, hasil negatif tersebut dapat disebabkan karena presisi dan akurasi uji bioassay yang kecil bila dibandingkan dengan pengujian lain yang lebih modern, misalnya uji AAS (Atom Absopsi Spetrophotometer) dan uji HPLC (High Performance Liquid
Chromatography). Apabila ingin mendapatkan hasil yang akurat terhadap jenis antiobiotika, dapat digunakan metode uji HPLC (High-Performance Liquid Chromatography). Meskipun demikian, bioassay merupakan metode yang sangat berguna untuk screening awal sejumlah besar sampel (Bueno et al., 2012).

Hasil penelitian yang sudah dilakukan sama dengan hasil yang dilakukan oleh Masrianto et al. (2013) pada daging sapi yang dipasarkan di pasar tradisional kota Banda Aceh. Hasil yang negatif tersebut membuktikan bahwa produk pangan asal sapi bali, yaitu hati dapat dikonsumsi oleh masyarakat. Tidak ditemukannya keberadaan residu antibiotika pada hati sapi bali, dapat disebabkan pemahaman peternak dalam penggunaan antibiotik sesuai dengan masa henti obat (withdrawal time) dan dosis yang tepat (Donkor et al., 2011).

\section{SIMPULAN}

\section{Simpulan}

Berdasarkan hasil uji residu antibiotika dengan metode bioassay dapat disimpulkan bahwa tidak ditemukan adanya residu antibiotika dari golongan penisilin, makrolida, tetrasiklin, dan aminoglikosida dalam sampel hati sapi bali yang diambil dari beberapa pasar daerah (Kabupaten Jembrana, Kabupaten Tabanan, Kabupaten 
Buleleng, Kabupaten Karangasem dan Kabupaten Gianyar) di Provinsi Bali

Saran

Monitoring produk asal hewan agar terus dilakukan. Perlu dilakukan penelitian lebih lanjut dengan meningkatkan jumlah sampel, jumlah pasar dan metode uji yang lebih baik, misalnya HPLC atau AAS. Uji residu antibiotika perlu dilakukan pada semua produk asal hewan ternak yang dikonsumsi oleh masyarakat, misaknya ayam, sapi, dan lainnya.

\section{UCAPAN TERIMAKASIH}

Ucapan terimakasih ditujukan kepada Kementerian Ristekdikti atas bantuan dana melalui hibah penelitian Unggulan Perguruan Tinggi melalui LPPM Universitas Udayana dengan kontrak No: 1023/UN14.9/LT/2016 dan Balai Besar Veteriner Denpasar Bali.

\section{DAFTAR PUSTAKA}

Amin LZ. 2014. Pemilihan Antibiotika yang Rasional. Medicinus. 27(3): 4045.

Atabani EAI, El-Ghareeb WR, Elabbasy MT, Ghazaly EI. 2014. Oxytetracycline residues in marketed Frozen beef livers at Sharkia, Egypt. Benha Vet. Med. J. 26(1): 104-112.

Bueno EC, Forastiero A, Tudela JLR, Estrella MC, Lopez AG. 2012. HPLC/UV or bioassay: two valid methods for posaconazole quantification in human serum samples. Clin. Microbiol. Infect. 18: 12.

Cohen L, Manion L, Morrison K. 2007. Research Methods in Education. Routledge. $6^{\text {th }}$ Ed. Pp. 101.

Dewi AAS, Widdhiasmoro NP, Nurlatifah I, Riti N, Purnawati D. 2014.Residu Antibiotika pada pangan asal hewan, dampak dan upaya penanggulangan. Buletin Veteriner, 26(85):

Dewi AM, Swacita IBN, Suwiti NK. 2016. Pengaruh perbedaan jenis otot dan lama penyimpanan terhadap nilai nutrisi daging sapi bali. Buletin Veteriner Udayana. 8(2): 135-144.
Donkor ES, Newman MJ, Tay SCK, Dayle NTKD, Bannerman E, Taiwo MO. 2011. Investigation into the risk of exposure to antibiotic residues contaminating meat and egg in Ghana. Food Control. 22: 869-873.

Goodman, Gilman's. 2011. The Pharmacological Basic of Therapeutics. United States: The McGraw-Hill Companies, Inc.

Gunawna IW, Suwiti NK, Sampurna P. 2016. Pengaruh pemberian mineral terhadap lingkar dada, panjang dan tinggi tubuh sapi bali jantan. Buletin Veteriner Udayana. 8(2): 128-134.

Lee MH, Lee HJ, Ryu PD. 2001. Public health risks: Chemical and antibiotic residues. Asian-Australasian J. Anim. Sci. 14(3): 402-413.

Mamani MCV, Reyes FGR, Rath S. 2009. Multiresidue determination of tetracyclines, sulphonamides and chloramphenicol in bovine milk using HPLC-DAD. Food Chem.117: 545552.

Marlina NA, Zubaidah E, Sutrisno A. 2015. Pengaruh pemberian antibiotika saat budidaya terhadap keberadaan residu pada daging dan hati ayam pedaging dari peternakan rakyat. J. Ilmu-Ilmu Peternakan. 25(2): 10-19.

Masrianto, Fakhrurrazi, Azhari. 2013. Uji residu antibiotika pada daging sapi yang dipasarkan di pasar tradisional kota Banda Aceh. J. Med. Veterinaria. 7(1): 13-14.

Meutia NR, Ridha S, Sari MK. 2016. Residu antibiotika dalam air susu segar yang berasal dari peternakan di wilayah Aceh Besar. J. Ilmu Ternak. 16(1): 1-5.

Nina MA, Elok Z, Aji S. 2015. Pengaruh pemberian antibiotika saat budidaya terhadap keberadaan residu pada daging dan hati ayam pedaging dari peternakan rakyat. J. Ilmu-Ilmu Peternakan.Fakultas Peternakan UB. 25(2): 10-19.

Ningrum SG. 2011. Pengujian residu antibiotika dalam susu segar dari beberapa peternakan sapi perah di 
Provinsi Jawa Barat menggunakan metode bioassay. Skripsi. Fakultas Kedokteran Hewan, IPB

Noor SM, Poeloengan M. 2005. Pemakaian antibiotika pada ternak dan dampaknya pada kesehatan manusia. Lokakarya Nasional Keamanan Pangan Produk Peternakan. Pp. 56-64.

Pikkemaat MG, Rapallini MLBA, Van DSO, Elfrink JWA. 2009. Comparison of three microbial screening methods for antibiotics using routine monitoring samples. Anal Chem. Act. 637: 298304.

Putri MA, Herawati D, Kurniaty N. 2015. Pengembangan metode analisis antibiotik tetrasiklin dalam hati ayam menggunakan kromatografi cair kinerja tinggi. Proc. Penelitian SpeSIA UNISBA. Pp. 79-85.

Standar Nasional Indonesia. Badan Standarisasi Nasional. SNI 01-63662000.
Standar Nasional Indonesia. Badan Standarisasi Nasional. SNI 7424:2008. Suranjaya IG, Ardika IN, Indrawati RR. 2010. Faktor-Faktor yang mempengaruhi produktivitas sapi bali di wilayah binaan proyek pembibitan dan pengembangan sapi bali di Bali. Majalah Ilmiah Peternakan. 13(13): 83-87.

Tajick MA, Shohreh B. 2006. Detections of antibiotics residue in chicken meat using TLC. Int. J. Poult. Sci. 5(7): 611612.

Wessenaar TM. 2005. Use of antimicrobial agents in veterinary medicine and implications for human health. Critical Rev. Microbiol. 31: 155-169.

Yuningsih. 2010. Keberadaan residu antibiotika dalam produk peternakan (Susu dan Daging). Lokakarya Nasional Keamanan Pangan Produk Peternakan. Pp. 48-55. 